DOI: https://doi.org/10.32689/2618-0065-2020-2(4)-202-213

Лахижа Микола Іванович, доктор наук 3 державного управління, професор, Інститут підготовки кадрів державної служби зайнятості України, професор кафедри публічного управління та адміністрування, вулиця Нововокзальна, 17, Київ, 03038 e-mail: Lahisha@ukr.net; тел.: 096-55-21-789, https//orcid.org/0000-0001-8676-4578

\title{
ДИДЖИТАЛІЗАЦІЯ В УКРАЇНІ: ПОНЯТТЯ, ПРОБЛЕМИ, ПЕРСПЕКТИВИ ТА ЗАВДАННЯ ПУБЛІЧНОГО УПРАВЛІННЯ
}

Анотація. У статті проведено аналіз впровадження електронної демократії та цифрової економіки і відповідних змін термінології публічного управління в Україні.

Метою дослідження визначено з'ясування причин активного розширення термінології сучасної української мови та зв’язку цього процесу з ходом реформ; виявлення суті окремих понять, доцільності їх використання у офіційних матеріалах; визначення перспектив диджиталізації, іiі особливостей в Україні та завдань з точки зору публічного управління.

Гіпотеза дослідження грунтується на сприйнятті е-демократії та еурядування не як технологічних рішень, а як новітньої концепції, що вимагає суттєвих змін публічного управління і має стати шансом для успішного розвитку України. Вживання нової термінології має об’єктивні підстави, проте повинне мати й обгрунтування та певні межі.

Висновки автора грунтуються на аналізі нормативно-правових джерел інформатизації, наукових досліджень та інтернет-ресурсів. Відзначено етапи інформатизації в Україні. Відмічено, що в Україні індивідуальні користувачі i дрібний бізнес значно випереджають державу, підштовхуючи ії до реформ. Відтак, автор стверджує про наявність певної обумовленості реформ, що викликано об'єктивними законами суспільного розвитку.

Наголошено, що активне використання термінів «диджиталізація», «перезавантаження», «перезапуск» є об’єктивним процесом, який відображає, насамперед, нестабільність українських реформ, відсутність їх послідовності й наступності, водночас має завдання спонукання, роз'яснення, спрощення, будучи проявом певної термінологічної еквілібристики. Цей висновок підтверджується порівнянням 3 практикою реформ у Болгарії та Польщі, де термінологія реформ набагато стриманіша.

Проблеми диджиталізації в Україні пов'язуються не лише і не скільки 3 технологічним відставанням, а й з недосконалістю публічного управління, яке 
відчуває значний вплив олігархів та піддається зовнішньому впливу. Отже, електронна демократія та цифрова економіка можуть ефективно розвиватися лише за умови подолання внутрішніх протиріч та досягнення національної єдності на основі національних цінностей.

Ключові слова: публічне управління, глобалізація, інформатизація, трансформація, модернізація, диджиталізація, перезавантаження, перезапуск.

Lakhyzha Mykola Ivanovych, Doctor of Science in Public Administration, Professor, Institute for Personal Training of the State Employment Service of Ukraine, Professor of the Department of Public Administration, 17 Novokovzalna Street, Kyiv, 03038, e-mail: Lahisha@ukr.net; tel.: 096-55-21-789, https//orcid.org/0000-0001-8676-4578

\title{
DIGITALIZATION IN UKRAINE: CONCEPT, PROBLEMS, PROSPECTS AND TASKS OF PUBLIC ADMINISTRATION
}

\begin{abstract}
The article analyzes the implementation of e-democracy and the digital economy and the corresponding changes in the terminology of public administration in Ukraine.

The aim of the study is to find out the reasons for the active expansion of the terminology of modern Ukrainian and to link this process with the progress of reforms; to identify the essence of certain concepts, expediency of their use in official materials; to define the perspectives of digitization, its peculiarities in Ukraine and the tasks in terms of public administration.

The research hypothesis is based on the perception of e-democracy and egovernment not as technological solutions but as a modern concept that requires significant changes in public administration and should become a chance for the successful development of Ukraine. The use of the new terminology has objective reasons, but there must be justification and some limits.

The author's conclusions are grounded on the analysis of regulatory and legal base of informatization, scientific researches and Internet resources. The stages of informatization in Ukraine are identified. It is noted that in Ukraine, individual users and small businesses are far ahead of the state, pushing it to reform. Therefore, the author argues for a certain conditionality of the reforms, which is caused by the objective laws of social development.

It is emphasized that the active use of the terms "digitization", "reloading", "restart" is an objective process, which reflects primarily the instability of Ukrainian reforms, the lack of their consistency and continuity, and at the same time has the task of encouraging, explaining, simplification, being a manifestation of a certain terminological equilibrium. This conclusion is supported by a comparison with the
\end{abstract}


practice of reforms in Bulgaria and Poland, where the terminology of reforms is much more restrained.

The problems of digitization in Ukraine are related not only to the technological backwardness, but also to the imperfection of public administration, which is heavily influenced by the oligarchs and is externally influenced. Therefore, e-democracy and the digital economy can develop effectively only if the internal contradictions will be overcome and the national unity based on national values will be achieved.

Keywords: public administration, globalization, informatization, transformation, modernization, digitization, reloading, restart.

Постановка питання. Нестабільність і хаотичність українських реформ вже неодноразово були предметом нарікань політиків та вчених.

Вихід із цього стану небезпідставно вбачається у впровадженні електронної демократії та цифрової економіки, що активно розвиваються у світі, трансформуючи життя людей і формуючи інформаційне суспільство. Відповідно у практику впевнено увійшли нові, пов’язані з глобалізацією, поняття, які характеризують сучасні суспільні відносини як інформаційні, цифрові, мережеві, віртуальні.

Кінець XX - початок XXI століття характеризується все глибшим проникненням інформаційно-комунікаційних технологій (ІКТ) у всі сфери життя суспільства, що змінює публічну адміністрацію та змушує іiі концентрувати увагу на використанні високих технологій в управлінських процесах при трансформації відносин між громадянами та владою.

Яскравим прикладом позитивного впливу інформатизації на розвиток країни стала одна з посткомуністичних держав - Естонія, яка здійснила ривок, що вважається дивовижним, але має реальні пояснення.

В Україні помітними кроками на шляху інформатизації стали:

1) прийняття Національної програми інформатизації (1998р.), у якій інформатизація розглядається як «сукупність взаємопов'язаних організаційних, правових, політичних, соціально-економічних, науковотехнічних, виробничих процесів, що спрямовані на створення умов для задоволення інформаційних потреб громадян та суспільства на основі створення, розвитку і використання інформаційних систем, мереж, ресурсів та інформаційних технологій, які побудовані на основі застосування сучасної обчислювальної та комунікаційної техніки» [ 1 ];

2) затвердження державних цільових програм Розвитку інформаційного суспільства (2007 р.) та Електронного урядування» (2010р.);

3) укладення угоди про Асоціацію Україна - СС (2014р.);

4) схвалення урядової концепції розвитку цифрової економіки в державі на 2018-2020 роки (2018 р.) тощо. 
Відповідні програми інформатизації діють на регіональному та місцевому рівнях, проте їх реалізація оцінюється неоднозначно.

Правомірним вважаємо зауваження технічного директора IT-Enterprise В. Михайлова, який вважає особливістю українського цифрового розвитку те, що «малий і середній бізнес вже так чи інакше працює в інтернеті і здебільшого використовує цифрові методи просування своїх послуг. Але держава і велика промисловість в Україні кардинально відстали» [ 2].

Все це дозволяє стверджувати про наявність певного стержня реформ, дотримання якого викликане об'єктивними законами суспільного розвитку. Громадянське суспільство «підштовхує» державу. Саме тому сьогодні ми можемо говорити про посилення уваги до інформатизації, що особливо помітно з інтенсифікації використання комп'ютерної термінології у всіх сферах життя, включаючи нормативно-правове забезпечення.

Індивідуальні користувачі краще знають комп'ютерну термінологію, ніж політичну, що пов'язано також з недоліками правопросвітницької роботи.

Водночас, в Україні помітного прориву в ефективності реформ не відбулося. Відповідно виникає питання щодо суті та напрямів інтенсифікації інформатизації, яка може стати інструментом цивілізаційного прориву.

Суттєвою видається й проблема правомірності та доцільності використання поняття «диджиталізація» та іншої нової термінології у сфері політики; необхідність вияснення глибини ії розуміння та мети застосування представниками органів влади: що це - спонукання, роз'яснення, спрощення, еквілібристика тощо.

Відповіді потребує також питання, які вже піднімають експерти (М. Прохоров): диджеталізація - «це вибране слово для хайпу, чи реальна цифрова трансформація?» (слово «хайп» теж увійщло в українську мову, означаючи інтенсивну рекламу, розкручування; а популярний словник «Словотвір» перекладає це слово як «проект», «інструмент для обдурювання» і навіть «надувництво», «дурисвіть», «ошукальня», «бульбашка» тощо).

Відоме також порівняння нових термінів 3 медіа-вірусом, який трактується як інформація, яка не має корисного змісту, але зацікавлює людей, через що набуває миттєвої популярності. (Термін (Media virus) введений американським фахівцем в галузі засобів масової комунікації Д. Ра́шкоффом (англ. Douglas Rushkoff) [ 3 ].

Крім того, використовуючи комп’ютерну термінологію, слово «диджиталізація» можна назвати «хабом» - сервером, вузлом мережі, який об’єднує інші поняття і коригується з поняттям «сервісна держава».

Аналіз останніх публікацій з проблематики інформатизації свідчить про значну увагу до неї як зарубіжних, так і вітчизняних вчених. Зокрема, в науці державного управління питання електронної демократії та електронного врядування, як нових форм функціонування суспільства та його взаємодії 3 владою, стали предметом дослідження таких авторів, як І. Арістова, В. Бабаєв, 
Н. Грицяк, В. Дрешпак, О. Орлов, А. Семенченко, С. Соловйов, С. Чукут та інші. Маємо також враховувати думку представників теорії державного управління, таких як: В. Баштанник, Р. Войтович, І. Грицяк, В. Дзюндзюк, Ю. Кальниш, І. Коліушко, В. Корженко, В. Мартиненко, Л. Приходченко, А. Рачинський, І. Розпутенко, В. Солових, Ю. Сурмін, Ю. Шаров та інші.

Активно осмислюється цифрова економіка 3 точки зору економічної науки, зокрема, вченими Інституту економіки та прогнозування Національної академії наук України.

Проте найпомітнішими нові тенденції розвитку відображаються в засобах масової інформації, де нова термінологія активно використовується не лише журналістами, а й політиками, навіть під час офіційних заходів та публікацій. Часто ці терміни залишаються незрозумілими для громадськості й вживаються згідно міри підготовки й розуміння авторів.

Метою нашого дослідження $\epsilon$ з'ясування причин активного розширення термінології сучасної української мови та зв’язку цього процесу з ходом реформ; визначення суті окремих понять, доцільності їх використання у розмовній мові та офіційних матеріалах; визначення перспектив диджиталізації та їі особливостей в Україні.

Гіпотеза дослідження грунтується на сприйнятті е-демократії та еурядування не як технологічних рішень, а як новітньої концепції розвитку, що вимагає суттєвих змін публічного управління і має стати шансом для успішного розвитку України. Відповідно, вживання нової термінології має об'єктивні підстави, проте повинне мати й певні межі та обгрунтування, що особливо стосується законодавчого процесу.

Виклад результатів дослідження. Філологами відмічено, що з другої половини 80-х років XX століття відбулися значні зміни у структурі, семантиці та стилістиці української мови, які свідчать про мобілізацію мовних ресурсів для вираження ціннісних переорієнтацій та формування нової системи пріоритетів українського суспільства. В їхній основі лежить демократизація суспільного життя [4, с. 9]. Відзначаються вестернізація (використання англомовних слів) та колоквіліалізація (орозмовлення) лексики. Потреба у розширенні можливостей мовного самовираження суспільства неминуче супроводжується зниженням мовної культури, широким використанням у літературі та офіційних документах розмовної мови, аж до шокуючого використання жаргонної лексики.

При цьому часто ігноруються діючі норми правопису української мови. Яскравим прикладом може бути використання винесеного нами у заголовок статті узагальнюючого терміну «диджиталізація», який $є$ калькою 3 англ. digitalization - переведення інформації в цифрову форму. (Більш технологічне визначення: цифрова трансмісія даних, закодованих у дискретні сигнальні імпульси). Всупереч відомому «правилу дев'ятки», згідно якого в українській мові у словах іншомовного походження (загальних і власних назвах) після 
літер д, т, 3, с, ц, ч. Ш, ж, р перед приголосними кореня використовується літера «и», на практиці ж частіше використовується форма «діджиталізація» [5].

Проведений нами аналіз вітчизняних та зарубіжних інтернет-ресурсів на предмет застосування термінології, що відноситься до розвитку інформаційного суспільства та економіки, підтверджує поширену точку зору про активізацію використання на побутовому рівні комп’ютерної термінології, яка проникає у всі сфери життя. Так, окрім узагальнюючого поняття «диджиталізація» та традиційних вже термінів «реформування», «модернізація», «оптимізація», «децентралізація», «деконцентрація», «реструктуризація», «трансформація» для позначення змін у сфері публічного управління все частіше використовують терміни «перезавантаження» та «перезапуск».

Більше того, комп’ютерні аналогії застосовуються для осмислення стану суспільства та держави. Так, Ю. Кисельова у 2010 році стверджувала, що у ситуації, що склалася в Україні в контексті перетворень, демократична система, по суті, "зависла". Бракує сталості всіх складових, які складають демократію. «Якщо "демократичний транзит" та консолідація демократії зависли в інститутах та часі, то й політична та соціальна система може перезавантажитися» [6].

Осмислюючи поняття «диджиталізація» варто взяти до уваги результати дослідження Л. Андерссон (Liri Andersson, консалтингова компанія This Fluid World) та Л. Ван дер Хейден (Ludo Van der Heyden, професор INSEAD), які наголошують, що диджиталізація - це реальність, 3 якою стикається практично кожна фірма, але керівники повною мірою не розуміють сутності змін цього типу [7]. На основі кількох досліджень цими авторами запропоновано 11 порад для лідерів бізнесу щодо суті поняття «диджиталізація», які можна, на наш погляд, вважати корисними i для публічної адміністрації (Таблиця 1).

Таблиця 1. Диджиталізація: одинадцять порад для лідерів

\begin{tabular}{|l|l|}
\hline Сфера & Суть поради \\
\hline \multirow{5}{*}{$\begin{array}{l}\text { Зовнішнє } \\
\text { середовище }\end{array}$} & $\begin{array}{l}\text { Об’єктивність розуміння середовища, в якому функціонує бізнес. } \\
\text { Потужний «зсув» у зовнішньому середовищі ставить під сумнів } \\
\text { існування не тільки окремих фірм, але й цілих галузей. }\end{array}$ \\
\hline & $\begin{array}{l}\text { Необхідний перегляд припущень, на яких грунтується місія компанії, iï } \\
\text { позиціонування в галузі, а також бізнес-модель і підходи до } \\
\text { провадження діяльності }\end{array}$ \\
\cline { 2 - 2 } & Потрібно чітко визначити зміст понять, пов’язаних із диджитал-сферою \\
\cline { 2 - 3 } & $\begin{array}{l}\text { Кожен член організації має розуміти зміст диджиталізації та } \\
\text { долучитись до цього процесу }\end{array}$ \\
\cline { 2 - 3 } & Опорою диджиталізації має стати корпоративна культура \\
\cline { 2 - 3 } & Диджиталізація потребує тіснішої співпраці всіх стейкхолдерів \\
\cline { 2 - 3 } & Важливо активніше взаємодіяти з громадськістю \\
\hline & Стратегічний процес стає безперервним \\
\hline
\end{tabular}




\begin{tabular}{|l|l|}
\hline Стратегія & $\begin{array}{l}\text { Все більшою мірою дані стають основним рушієм процесу прийняття } \\
\text { рішень }\end{array}$ \\
\cline { 2 - 2 } & Диджилалізація спонукає фірми освоювати «невідомі території» \\
\cline { 2 - 2 } & Сутність диджиталізації полягає у безупинності змін \\
\hline
\end{tabular}

Підготовлено автором на основі: 7; 8

Серед інших порад найбільшої, на нашу думку, уваги лідерів публічного управління заслуговують тези щодо безперервності змін, свідомого розуміння суті процесів публічними службовцями та залучення громадськості.

Іншими новими поширеними термінами стали поняття «перезавантаження» та «перезапуск», які використовуються як аналогічні (restart - повторний запуск, перезапуск, перезавантаження, рестарт). Їх використання щодо суспільних процесів в українських засобах масової інформації можна відзначити вже з початку 2000-х років під впливом не лише розвитку інформаційних технологій, а й демонстрації концептуального фільму «Матриця. Перезавантаження» (2003 р.), впровадження політики «перезавантаження відносин з Росією» Президента США Б. Обами (2009р.) тощо.

Як наголошує Ю Сколоздра, ідею перезавантаження України вперше почали озвучувати ще після Помаранчевої революції. «Друге дихання» у неї вдихнули за часів президентства Януковича: тоді напрямок руху країни був абсолютно незрозумілим, і поки «Сім'я» підгрібала під себе країну, у багатьох українців вперше почало з'являтись відчуття безвиході» [ 9 ]. Наступне перезавантаження стало можливим у 2014 році, але дві революції не змогли ні змінити ні корумповану політичну еліту, ні політичну систему, які є головними гальмами реформ та розвитку країни.

У монографії І. Розпутенка (2014 р.) вказувалося на необхідність відходу від політики «модернізації» та «вдосконалення» і переходу з 2015 року до «перезавантаження держави». «Перезавантаження - це процес деколонізації, кадрової люстрації, декриміналізації (корупція), антитоталітаризації, демократизації. Перезавантаження - це процес наповнення інститутів держави національними цінностями, українськими традиціями, українською історією, українською мовою, процес оптимізації (затрати/результати) державної політики, процес відповідностей моральних цінностей і цілей держави» [10, c.14].

Як відзначає С. Сорока, з "перезавантаження" влади починає свою діяльність чи не кожний новий уряд України, закінчуючи, як завжди традиційним популізмом i "перезавантаженням" урядовців на керівних посадах. Так, "турборежим" і "перезавантаження" були цілком свідомо обрані новим президентом та його командою, щоб щонайшвидше схвалити важливі реформаторські закони, а також паралельно провести на всі принципові посади державної служби націлених на реформу, і не "заплямованих" в минулих урядах людей» [11]. 
Водночас помітним є розходження теорії з практикою, що стосується не лише незатребуваності наукових напрацювань, а й розуміння необхідності змін та їх практичного наповнення. Наприклад, у лютому 2016 року тодішній Голова Верховної Ради України В. Гройсман відзначав: "Суть перезавантаження, яка зараз обговорюється, полягає в першу чергу в зміні системи управління, а не лише в заміні одних прізвищ, на інші. На жаль, і центральні, і місцеві органи влади досі продовжують визначати свою ефективність прийнятими рішеннями, а не тим, що в результаті змінилося для людей. Процесуальний підхід потрібно замінити на підхід, орієнтований на результат» [12].

C. Сорока використовує також термін "недоперезавантаження" державного управління, чим на його думку, закінчились реформа урядів Азарова, Яценюка, Гройсмана та Гончарука.

Отже, перезавантаження та перезапуск є ознакою нештатної ситуації, прагнення виправити ситуацію шляхом зміни алгоритму дій та зміни кадрового складу органів влади.

Як «повне перезавантаження влади в Україні» в пресі оцінювався початок децентралізації у 2014 році. У наступні роки йшлося вже про перезавантаження децентралізації, соціального діалогу, системи земельних відносин, «велике перезавантаження» тощо. Як перезавантаження оцінювався прихід до влади нової команди у 2019 році, а потім йшлося про перезавантаження Верховної Ради, Кабінету Міністрів, інших владних інституцій. Йдучи у відставку, Прем’єр-міністр стверджував, що робота його Кабміну заклала фундамент для перезавантаження країни. Водночас поняття «перезавантаження» все більше використовується у інших сферах, в основному для переоцінки явищ та процесів

Термін «перезапуск» використовувався як Президентом, так і іншими українськими політиками та журналістами щодо економіки, демократії, відносин Україна-НАТО, а також - Кабінету Міністрів України та ДБР, ДФС, НАЗК, СБУ та інших структур.

У 2016 році неодноразово висловлювалися пропозиції щодо «перезаснування» України, які стримувалися питанням: «Хто його буде здійснювати?». Явними були розходження й щодо історичного зразку: гетьманат Сагайдачного чи УНР?

Використання нової термінології в процесі публічного управління стало нормою у 2019 році. Децентралізація і диджиталізація розглядалися як фактори формування нової еліти [13 ], а реальні зміни пов’язувалися 3 дерегуляцією, децентралізацією та диджиталізацією [14].

Та найяскравішим прикладом колоквіліалізації, підтвердженням мовної повноправності та широти застосування нового поняття, а, водночас, й недбалого відношення до формування букви закону, стало офіційне використання розмовного терміну у назві Закону України «Про внесення змін 
до деяких законів України щодо перезавантаження влади» [15]. При цьому законодавцями не було враховано висловлені у експертному висновку на проект закону зауваження, що юридичний зміст терміну «перезавантаження» - неясний, а назва закону не повністю відповідає змісту, оскільки проект сконцентрований на внесенні змін до правового статусу державних службовців [16]. Крім того, експертами ці зміни оцінювалися в основному негативно, оскільки порушували процес створення сучасної державної служби, розпочатий у попередні роки, посилюючи маніпулятивні можливості урядовців відносно державних службовців.

Очевидно, що в даному випадку проявилася низка факторів впливу, основними з яких, на нашу думку, став «турборежим» роботи Верховної Ради України, бажання популяризувати дії влади (популізм) та прагнення полегшити можливість ручного керування державною службою.

Оцінюючи практику вживання термінів «перезавантаження» та «перезапуск», слід наголосити, що в обох випадках особливо важливе значення має точка відліку, точка повернення, програма змін, яка зафіксована в Конституції України та документах, що передбачають європейську інтеграцію.

Вивчення нами практики реформ у посткомуністичних країнах (Болгарія [17], Польща [18]) показує, що інформаційна революція є й для них важливим завданням, що знаходить відображення й у термінології, проте поняття «перезавантаження» використовується не часто, й насамперед, стосовно зміни зовнішніх відносин.

В Україні ж перезавантаження стає нормою внаслідок невикористаних можливостей. Так, у 2010 році відомий американський політолог 3. Бжезінський відзначав, що те, через що проходить Україна сьогодні, на превеликий жаль, нагадує те, через що пройшла Польща у вісімнадцятому сторіччі. У Польщі тоді фактично домінувала аристократична, заможна еліта 3 різними особистими інтересами, і країною маніпулювали зовнішні сили [19], а експерт С. Дацюк пише про виродження революції (11.2019р.), пов’язуючи його 3 інтелектофобськими, обивательскими, ресентиментальними, компрадорськими внутрішніми діями, які також можуть мати зовнішні стимули [20].

Висновки. Проведене дослідження переконливо, на нашу думку, свідчить про об’єктивну необхідність інформаційної трансформації України, яка все частіше позначається терміном «диджиталізація».

Використання цього та низки інших термінів, насамперед, «перезавантаження», «перезапуск», «перезаснування» відображає в першу чергу нестабільність українських реформ, відсутність їх послідовності й наступності, водночас має завдання спонукання, роз'яснення, спрощення, будучи проявом певної термінологічної еквілібристики i, значною мірою, агресивною рекламою - хайпом. Цей висновок підтверджується порівнянням 
3 практикою реформ у Болгарії та Польщі, де термінологія реформ набагато стриманіша.

Проблеми диджиталізації в Україні пов'язані не лише і не скільки 3 технологічним відставанням, а й з недосконалістю публічного управління. Влада відчуває значний вплив олігархів, піддається зовнішньому впливу, а відтак - вдається до популізму. Державна ж служба залишається нестабільною і політизованою, що посилилося внаслідок внесення останніх змін до закону.

Отже, електронна демократія та цифрова економіка можуть створюватися лише за умови подолання внутрішніх протиріч, досягнення національної єдності на основі національних цінностей, впровадження не лише сучасних технологій, а й сучасної системи публічного управління.

\section{Jimepamypa:}

1. Про Національну програму інформатизації. Закон Украӥни від 4 лютого 1998 року № 74/98-BP. URL: https://zakon.rada.gov.ua/laws/show/74/98-\%D0\%B2\%D1\%80

2. Україна переходить на “цифрову економіку”. Що це означає. АНАЛІТИКА. 21.01.2018. URL: https://www.ukrinform.ua/rubric-society/2385945-ukraina-perehodit-nacifrovu-ekonomiku-so-ce-oznacae.html

3. Семенюк Г. С. «Зе» як медіавірус: специфіка і трансформації //Актуальні проблеми медіапростору : матеріали конферениї. Київ, Київський інститут журналістики КНУ Шевченка, 2019. С. 180-185.

4. Татаренко О. Актуалізовані моделі в системі словотворення сучасної української мови (кінець XX - початок XXI ст.). Монографія. К.: Видавничий дім Дмитра Бураго. 2015. 248 c.

5. Правопис слів іншомовного походження. Ділова мова. URL: https://www.dilovamova.com/index.php?page $=4 \& d m u a=31 \& t d m u a=\% F F$

6. Кисельова Ю. Уроки демократичного транзиту в Україні. Проект, що перезавантажується навпаки. Українська правда 4.05.2010 URL: https://www.pravda.com.ua/articles/2010/05/4/4996559/

7. Directing Digitalisation Guidelines for Boards and Executives. By Liri Andersson, this fluid world and Ludo Van der Heyden, INSEAD.February 2017 URL: http://www.thisfluidworld.com/wp-content/uploads/2017/02/Corporate-governance-February2017.pdf

8. Диджиталізація: одинадцять порад для лідерів. MANAGEMENT.COM.UA. 20/06/2017. URL: http://www.management.com.ua/tend/tend922.html

9. Сколоздра Ю. «Перезаснування» України на засадах УНР: «за» і «проти» ВГОЛОС. 28.10.2016 URL: https://vgolos.com.ua/articles/perezasnuvannya-ukrayiny-nazasadah-unr-za-i-proty_232914.html

10. Розпутенко І. Третє тисячоліття - Україна і неоколоніалізм. К. Вид-во «K.I.C.». 2014. $356 \mathrm{c}$.

11. Сорока C. Перезавантаження державної служби: прорив чи реванш? URL: https://www.pravda.com.ua/columns/2020/01/9/7236868/

12. Гройсман: Перезавантаження влади - це зміна системи управління Сьогоднi. 11 лютого 2016. URL: https:/www.segodnya.ua/ua/politics/groysman-perezagruzka-vlasti-etoizmenenie-sistemy-upravleniya-690984.html

13. Сас О. Децентралізація + діджиталізація = нова управлінська еліта України Децентралізація дає можливості. 15.05.2019.URL: https://decentralization.gov.ua/news/11014 
14. Квітка Г. Прийшов з дерегуляцією, децентралізацією та діджиталізацією. Голос України. 6.12.2019. URL: http://www.golos.com.ua/article/324990

15. Про внесення змін до деяких законів України щодо перезавантаження влади. Закон України від 19 вересня 2019 року № 117-IX URL: https://zakon.rada.gov.ua/laws/show/117-20

16. Висновок на проект Закону України «Про внесення змін до деяких законів України щодо перезавантаження влади» (реєстр. № 1066 від 29.08.2019 р.) URL: https://w1.c1.rada.gov.ua/pls/zweb2/webproc4_1?pf3511=66291

17. Лахижа М.I. Модернізація публічної адміністрації: досвід Республіки Болгарія. Монографія. Полтава: ПолтНТУ, 2014. 208 с.

18. Лахижа М.I. Модернізація публічної адміністрації: досвід Республіки Польща. Монографія. Полтава: ПолтНТУ, 2012. 243 с

19. Домбровський О. Україна: "перезавантаження" чи "втрачений файл"? Украӥнська правда. 19.07.2010. URL: https://www.pravda.com.ua/archives/date_19072010/

20. Дацюк С. Виродження революції. Украӥнська правда. 26.11.2019 URL:https://blogs.pravda.com.ua/authors/datsuk/5ddd1b209a00b/

\section{References:}

1. Pro Natsionalnu prohramu informatyzatsii. Zakon Ukrainy vid 4 liutoho 1998 roku № 74/98-VR. URL: https://zakon.rada.gov.ua/laws/show/74/98-\%D0\%B2\%D1\%80 [in Ukrainian].

2. Ukraina perekhodyt na "tsyfrovu ekonomiku". Shcho tse oznachaie. ANALITYKA. 21.01.2018. URL: https://www.ukrinform.ua/rubric-society/2385945-ukraina-perehodit-nacifrovu-ekonomiku-so-ce-oznacae.html [in Ukrainian].

3. Semeniuk H. S. (2019). «Ze» yak mediavirus: spetsyfika i transformatsii //Aktualni problemy mediaprostoru : materialy konferentsii. Kyiv, Kyivskyi instytut zhurnalistyky KNU Shevchenka, S. 180-185. [in Ukrainian].

4. Tatarenko O. (2015) Aktualizovani modeli v systemi slovotvorennia suchasnoi ukrainskoi movy (kinets KhKh - pochatok KhKhI st.). Monohrafiia. K.: Vydavnychyi dim Dmytra Buraho. [in Ukrainian].

5. Pravopys sliv inshomovnoho pokhodzhennia. Dilova mova. URL: https://www.dilovamova.com/index.php?page=4\&dmua=31\&tdmua= \%FF[in Ukrainian].

6. Kyselova Yu. Uroky demokratychnoho tranzytu v Ukraini. Proekt, shcho perezavantazhuietsia navpaky. Ukrainska pravda 4.05.2010 URL: https://www.pravda.com.ua/articles/2010/05/4/4996559/[in Ukrainian].

7. Directing Digitalisation Guidelines for Boards and Executives. By Liri Andersson, this fluid world and Ludo Van der Heyden, INSEAD.February 2017 URL:

http://www.thisfluidworld.com/wp-content/uploads/2017/02/Corporate-governance-February2017.pdf

8. Dydzhytalizatsiia: odynadtsiat porad dlia lideriv. MANAGEMENT.COM.UA. 20/06/2017. URL: http://www.management.com.ua/tend/tend922.html[in Ukrainian].

9. Skolozdra Yu. «Perezasnuvannia» Ukrainy na zasadakh UNR: «za» i «proty» VHOLOS. 28.10.2016 URL: https://vgolos.com.ua/articles/perezasnuvannya-ukrayiny-nazasadah-unr-za-i-proty_232914.html [in Ukrainian].

10. Rozputenko I. (2014). Tretie tysiacholittia - Ukraina i neokolonializm. K. Vyd-vo «K.I.S.». [in Ukrainian].

11. Soroka S. Perezavantazhennia derzhavnoi sluzhby: proryv chy revansh? URL: https://www.pravda.com.ua/columns/2020/01/9/7236868/[in Ukrainian].

12. Hroisman: Perezavantazhennia vlady - tse zmina systemy upravlinnia Sohodni. 11 liutoho 2016. URL: https://www.segodnya.ua/ua/politics/groysman-perezagruzka-vlasti-etoizmenenie-sistemy-upravleniya-690984.html[in Ukrainian]. 
13. Sas O. Detsentralizatsiia + didzhytalizatsiia = nova upravlinska elita Ukrainy Detsentralizatsiia daie mozhlyvosti. 15.05.2019. URL:

https://decentralization.gov.ua/news/11014

14. Kvitka H. Pryishov z derehuliatsiieiu, detsentralizatsiieiu ta didzhytalizatsiieiu. Holos Ukrainy. 6.12.2019. URL: http://www.golos.com.ua/article/324990[in Ukrainian].

15. Pro vnesennia zmin do deiakykh zakoniv Ukrainy shchodo perezavantazhennia vlady. Zakon Ukrainy vid 19 veresnia 2019 roku № 117-IX URL:

https://zakon.rada.gov.ua/laws/show/117-20[in Ukrainian].

16. Vysnovok na proekt Zakonu Ukrainy «Pro vnesennia zmin do deiakykh zakoniv Ukrainy shchodo perezavantazhennia vlady» (reiestr. № 1066 vid 29.08.2019 r.)

URL:https://w1.c1.rada.gov.ua/pls/zweb2/webproc4_1?pf3511=66291[in Ukrainian].

17. Lakhyzha M.I. (2014). Modernizatsiia publichnoi administratsii: dosvid Respubliky Bolhariia.- Poltava: PoltNTU. [in Ukrainian].

18. Lakhyzha M.I. (2012). Modernizatsiia publichnoi administratsii: dosvid Respubliky Polshcha.Poltava: PoltNTU [in Ukrainian].

19. Dombrovskyi O. Ukraina: "perezavantazhennia" chy "vtrachenyi fail"? Ukrainska pravda. URL: 19.07.2010. https://www.pravda.com.ua/archives/date_19072010/ [in Ukrainian].

20. Datsiuk S. Vyrodzhennia revoliutsii. Ukrainska Pravda. 26.11.2019 URL:https://blogs.pravda.com.ua/authors/datsuk/5ddd1b209a00b/ [in Ukrainian]. 